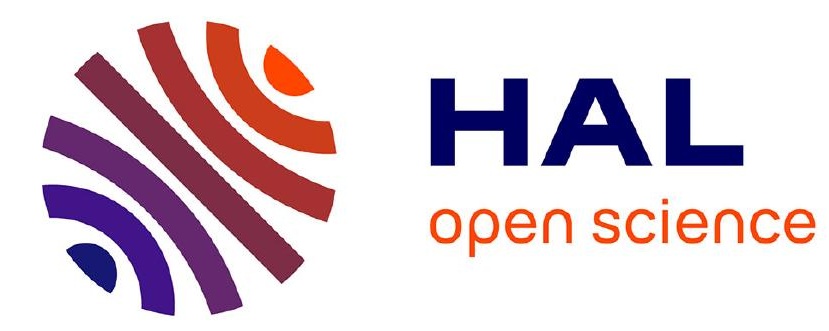

\title{
Analytical Bioelectrochemistry
}

Daniel R. Thevenot

\section{To cite this version:}

Daniel R. Thevenot. Analytical Bioelectrochemistry. R. Kalvoda; R. Parsons. Electrochemistry in research and development, Plenum Publishing Corporation, pp.181-188, 1985, 10.1007/978-1-46845098-9_19. hal-01179335

\section{HAL Id: hal-01179335 \\ https://hal.science/hal-01179335}

Submitted on 22 Jul 2015

HAL is a multi-disciplinary open access archive for the deposit and dissemination of scientific research documents, whether they are published or not. The documents may come from teaching and research institutions in France or abroad, or from public or private research centers.
L'archive ouverte pluridisciplinaire HAL, est destinée au dépôt et à la diffusion de documents scientifiques de niveau recherche, publiés ou non, émanant des établissements d'enseignement et de recherche français ou étrangers, des laboratoires publics ou privés. 
D. R. Thévenot

Laboratoire de Bioélectrochimie Université Paris-Val de Marne

94010 Créteil Cedex, France

\section{INTRODUCTION}

Among the various analytical methods using biochemistry or physiochemistry bioelectrochemistry is one of the most active and rapidly deve1oping fields. It is indeed rarely necessary to add any chemical in the sample, thus allowing direct in vivo application of these methods, and their selectivity and sensitivity is often sufficient to avoid any separative or concentrative step. Besides the direct monitoring of a given species and of its reacting properties analytical bioelectrochemistry is also able to follow the heterogeous reactions occurring at a metal-solution inter-face with biopolymers such as nucleic acids or proteins and evaluate their conformation $[1,2]$.

This introduction to the session devoted to electrochemistry in biosciences is intended to present briefly the various methods used in analytical bioelectrochemistry with a particular emphasis on in vivo sensors (Table 1).

\section{METAL-SOLUTION INTERFACE SENSORS}

Non-destructive Methods: Use of Microelectrodes

The use of carbon or mercury micro-cathodes and platinum or carbon micro-anodes enables the identification of a compound by the potential necessary for its reduction or oxidation. It enables also the quantitative determination of such compounds using either limiting currents in steady-state methods - or peak currents - in transient method.

Detection limits reach ca $1 \mathrm{nM}$ when background or capacitive currents are filtered or compensated, in transient methods such as differential pulse polarography (DPP) or voltammetry. Numerous redox molecules, either metabolites or drugs, may be determined in biological samples either directly or after an extraction procedure $[3,4]$. Particularly miniaturized electrodes using carbon fibers or paste may be implanted and allow the continuous monitoring of some metabolites and drugs in neuronal tissues or arteries [5-8]. 
Table 1. Main Characteristics of Bioelectrochemical Sensors

\begin{tabular}{|c|c|c|c|c|}
\hline $\begin{array}{l}\text { Sensor } \\
\text { type }\end{array}$ & $\begin{array}{c}\text { Metal } \\
\text { electrode }\end{array}$ & $\begin{array}{c}\text { Ion selective } \\
\text { electrode } \\
\text { (ISE) }\end{array}$ & $\begin{array}{c}\text { Gas selective } \\
\text { electrode } \\
\text { (GSE) }\end{array}$ & $\begin{array}{l}\text { Enzyme of } \\
\text { whole cell } \\
\text { electrode }\end{array}$ \\
\hline $\begin{array}{l}\text { Detected } \\
\text { species }\end{array}$ & $\begin{array}{l}\text { Electroactive } \\
\text { (oxidant or } \\
\text { reducer) }\end{array}$ & $\begin{array}{l}\text { Inorganic } \\
\text { ions }\end{array}$ & $\begin{array}{l}\text { Electroactive } \\
\text { or acid-base } \\
\text { gases }\end{array}$ & $\begin{array}{l}\text { Metabolites } \\
\text { inhibitors }\end{array}$ \\
\hline $\begin{array}{l}\text { Electro- } \\
\text { chemical } \\
\text { detector }\end{array}$ & $\begin{array}{l}\text { Metal + ref } \\
\text { electrode }\end{array}$ & $\begin{array}{l}2 \text { ref. electr. } \\
\text { IFSET + ref. }\end{array}$ & $\begin{array}{l}2 \text { ref. electr. } \\
\text { metal }+ \text { ref }\end{array}$ & $\begin{array}{l}\text { Metal + ref. } \\
\text { ISE, GSE }\end{array}$ \\
\hline \multirow[t]{2}{*}{ Membrane } & Without & $\begin{array}{l}\text { Glass } \\
\text { crystal } \\
\text { organic }\end{array}$ & $\begin{array}{l}\text { Hydrophobic } \\
\text { polymer } \\
\text { permeable }\end{array}$ & $\begin{array}{l}\text { Hydrophylic } \\
\text { polymer with } \\
\text { immobilized }\end{array}$ \\
\hline & & & to gas & enzyme or cells \\
\hline $\begin{array}{l}\text { Properties } \\
\text { of the } \\
\text { analyte }\end{array}$ & $\begin{array}{l}\text { Electrochem. } \\
\text { reduction or } \\
\text { oxidation }\end{array}$ & $\begin{array}{l}\text { Specific ionic } \\
\text { conductivity } \\
\text { of membrane }\end{array}$ & $\begin{array}{l}\text { Gas diffusion } \\
\text { and redox or } \\
\text { acid-base }\end{array}$ & $\begin{array}{l}\text { Enzyme or ce } 11 \\
\text { catalyzed } \\
\text { reaction }\end{array}$ \\
\hline $\begin{array}{l}\text { Calibration } \\
\text { curve }\end{array}$ & $\begin{array}{l}I \text { vs } c \\
q \underline{v s} c\end{array}$ & $\mathrm{E} \underline{\mathrm{vs}} \log \mathrm{c}$ & $\begin{array}{l}\mathrm{E} \frac{\mathrm{vs}}{\mathrm{VS}} \mathrm{log} \mathrm{c} \\
\mathrm{I}\end{array}$ & $\begin{array}{l}\mathrm{I} \text { vs } \mathrm{c} \\
(\mathrm{dI} / \mathrm{d} t)_{\max } \mathrm{vs} \mathrm{c} \\
\mathrm{E} \underline{\mathrm{vs}} \log \mathrm{c}\end{array}$ \\
\hline $\begin{array}{l}\text { Response } \\
\text { type }\end{array}$ & $\begin{array}{l}\text { Steady state } \\
\text { transient }\end{array}$ & Equilibrium & $\begin{array}{l}\text { Equilibrium } \\
\text { steady state }\end{array}$ & $\begin{array}{l}\text { Steady state } \\
\text { transient }\end{array}$ \\
\hline
\end{tabular}

Destructive Methods: Coulometry

These methods, which to our knowledge are only used in vitro, enables the determination of a compound by its complete oxidation or reduction on a macroelectrode at a fixed potential or current: current is integrated till the electrochemical detection of the final point. Coulometry may be either direct if the analyte is electroactive, such as seric iron, or indirect: the electrogenerated reagent may then be:

- a complexing agent, such as $\mathrm{Ag}^{+}, \mathrm{Hg}^{+}$of $\mathrm{Hg}^{++}$

- a strong oxidant, such as bropine, $\mathrm{Ag}^{\mathrm{Hf}}, \mathrm{Mn}^{+1+}$ or $\mathrm{Au}^{+1+}$,

- a strong reducer, such as $\mathrm{Ti}^{+7}$ or viologen radical cations[9].

Because of their coulometric origin, if the end point is well determined, all these methods are absolute and do not need any calibration. Some clinical instruments, such as blood chloride meters, use such $\mathrm{Ag}^{+}$ generated coulometries.

An alternative to these method was originally proposed by Bruckenstein and Albery[10-12] and used with biological species or samples by Rauwell and Thévenot[13-15]: with a rotating ring-disk electrode a reactant is electrogenerated on the disk, reacts with the analyte in the vicinity of the electrode and its excess is eventually detected on the ring. When titration reaction is rapid enough, detection limit of this non-destructive alternative to indirect coulometry reaches $100 \mathrm{nM}$.

Another alternative to, or more precisely, application of in vivo coulometry has recently been proposed by Albery for long term implanted carbon electrodes: a controlled electrolysis on a brain microelectrode 
surrounded by living cells allows the oxidation of ascorbate and thus its elimination in a further anodic voltammogram: it is therefore possible to detect much lower concentration of neurotransmitters or of their metabolites and study the effect of chronic drug treatment $[5,8,16]$.

\section{ION SELECTIVE ELECTRODES (ISE)}

Glass, crystalline and organic membranes which present specific ionic conductivity have been intensively used for direct determination of ion activity. Measurement of membrane potentials using either 2 reference electrodes such as $\mathrm{Ag} / \mathrm{AgCl}, \mathrm{Cl}-$ or $\mathrm{Hg} / \mathrm{Hg} 2 \mathrm{Cl2}, \mathrm{Cl}-[17-19]$ or a field effect transistor (ISFET) and a reference electrode[20] allows the determination of ion activities. Most of the present studies involve the preparation and characterization of organic membranes impregnated with water insoluble compounds specifically chelating some ions.

Such ISE are being progressively introduced into clinical laboratories for hydrogen, sodium, potassium and calcium ion determination $[21,22]$. Miniaturized models have been developed for in vivo intra-tissue or intracellular ion determinations[23-27] and for the detection of foetal suffering during delivery by detecting a slight $\mathrm{pH}$ decrease in the scale tissue $[28]$.

\section{GAS SELECTIVE ELECTRODES (GSE)}

Some gases may be selectively detected: they need to be either electroactive (oxygen, bromine) or acido-basic (carbon dioxide, sulfhydric acid, ammonia) and diffuse through an hydrophobic membrane (teflon, polyethylene). Thus such GSE are generally built with a metal or a $\mathrm{pH}$ electrode covered with a gas permeable membrane $[17,18,29,30]$.

Very frequently used in analytical laboratories, GSE have been introduced into clinical laboratories in the last few years for the direct determination of blood gases on very small samples[31] and for intravascular monitoring of oxygen, tension of blood[32,34]. Non-invasive transcutaneous oxygen or carbon dioxide electrodes may alternatively be placed on the surface of the heated skin of neonates or adults: the electrode response is directly proportional to arterial oxygen and carbon dioxide tensions [34-38].

\section{ENZYME OR CELL ELECTRODES}

This last type of specific electrode is certainly the most versatile but also, and this is often ignored, the most complex one. One or several enzymes are immobilized on a membrane by entrapment, adsorption, coreticulation or covalent coupling[39-41]. Alternatively bacterial or vegetal whole cells are entrapped or fixed on a membrane[41,42]. When such membrane are placed in class vicinity to an appropriate electrochemical detector, it is possible to associate the extremely selective properties of enzymes and the versatility of the previously mentioned electrochemical sensors. Indeed several tens of such electrodes have been described in the literature for the determination of either metabolites (enzyme or cell substrates) or toxic compounds (enzyme inhibitors); more recently, immunoenzymatic electrodes have been described using immobilized enzymes coupled to antibodies.

Since the pioneer work of Clark in 1962[43], several hundred publications and several international meetings have been devoted to enzyme electrodes and especially to glucose sensors $[39,40)$. However very few instruments are commercially available besides the glucose sensor com- 
mercialized for several years by Yellow Spring Instrument. One may find in France glucose sensors made by Solea Tacussel and Seres and a lactate sensor made by Setric; these enzyme electrodes are respectively based upon the previous research activity of Thévenot, Coulet and Gautheron [44,45] and Romette and Thomas [46] and of Durliat and Comtat [47]. Such a small number of commercially available sensors and instruments is mainly related to the complexity of the heterogeneous kinetics and thermodynamics involved in these sensors, but also to the usually poor characterization of the membrane and sensing head and to the absence of theory taking into account the numerous experimental parameters.

The major interest and possibilities of such sensors for clinical, fermentation control and food industry control and on-line analysis have led several research groups to spend time and effort for a better understanding of enzyme electrodes. This effort is even more important for in vivo devices and especially for the glucose sensing part of an artificial pancreas [40]: extra-corporal closed-loop devices have for example been developed and tested on animals by Abel in Karlsburg [48,49], whereas needle-type glucose sensors have been presented by Shichiri[50,51]. Both devices include multimembrane systems for enzyme entrapment, glucose and oxygen flux regulation, and protection from blood clotting. For such in vivo glucose sensors it is indeed necessary to solve several specific problems simultaneously.

- glucose concentration is usually much larger in blood than the Michaelis constant for glucose oxidase,

- oxygen concentration is different in blood and in air-saturated solution and may vary upon ventilation,

- hydrodynamical conditions, i.e. blood velocity in the sensor vicinity, may vary or be poorly controlled especially if the glucose sensor is implanted subcutaneously,

- response time should be smaller than 2-5 min for a good insulin regulation,

- glucose oxidase being normally absent from blood should not be released by the sensor.

In collaboration with Reach from the Faculté Villemin of the Paris University, we have studied these problems using an extra-corporal blood circulation in a conscious freely-moving rat (Figure 1). Preliminary results obtained during intravenous glucose tolerance test (IVGTT) have given interesting results when an in vivo calibration was performed and when the delay period of our device, i.e. response time + circulation time, was taken into account (Figure 2 and 3 ). Studies are in progress in order to compare results obtained with different enzymatic membranes and to characterize the most important parameters (permeabilities, partition coefficients, enzyme load and activity) of such membranes.

\section{CONCLUSION}

This rapid survey of present possibilities of analytical bioelectrochemistry shows that the following research fields are particularly active:

a) ultra-microelectrodes implanted in neuronal tissues, intravascularly or subcutaneously in order to monitor continuously in vivo electroactive species, ions or metabolites,

b) development of ISE or ISFET using organic ion conducting membranes and studying alternatives to the external reference electrode,

c) specific electrodes using either immobilized enzymes or whole cells in which the vessel and electrode design is optimized for a given application, 


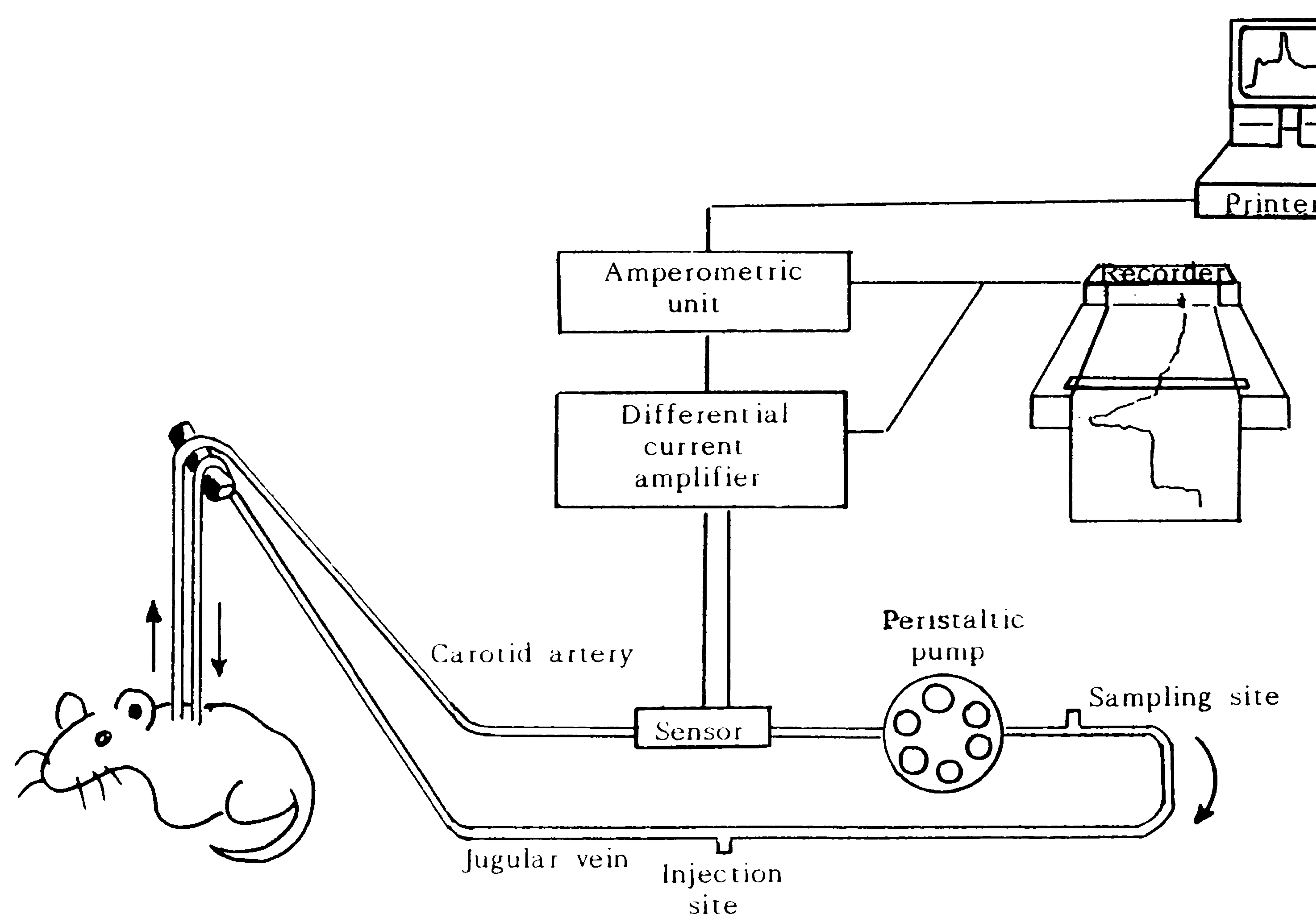

Fig. 1. Schematic diagram of in vivo evaluation of glucose sensor on conscious freely-moving rat.

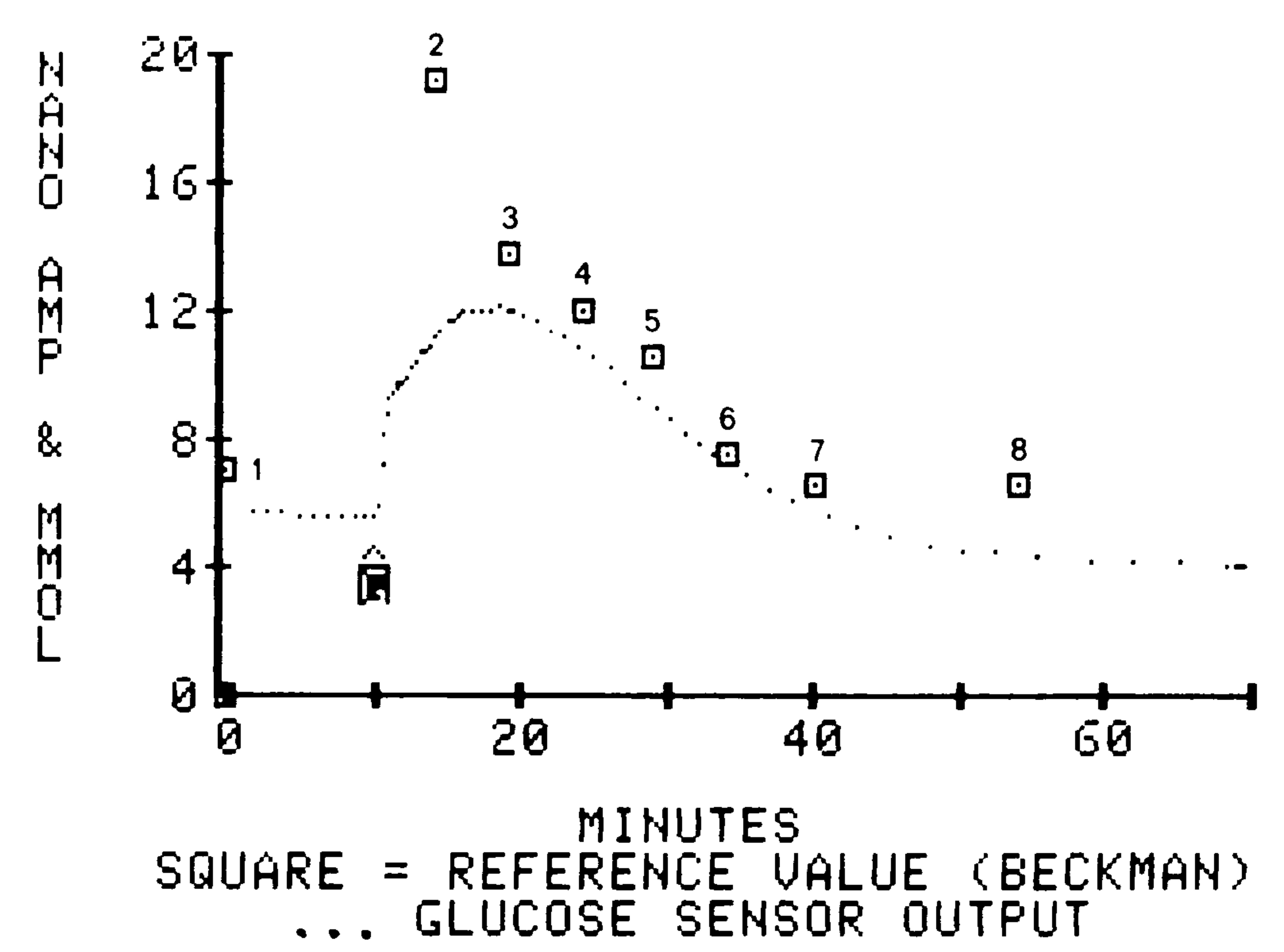

Fig. 2. Intravenous glucose tolerance test (IVGTT) on a sensor connected to a conscious freely-moving rat. (...) direct signal from glucose sensor using a glucose oxidase cellulose acetate membrane, (o) reference values using a Beckman glucometer.

d) and finally, development of modern instrumentation using autocalibration and control procedures associated with signal processing and interpretation. This latter field is of great importance in clinical applications.

The following paper, presented by Wightman, gives a more detailed review on implanted ultramicroelectrodes especially developed for neuronal tissue. The continuous monitoring of neurotransmitters and their metabolites is indeed one of the present challenges of analytical bioelectrochemistry. 


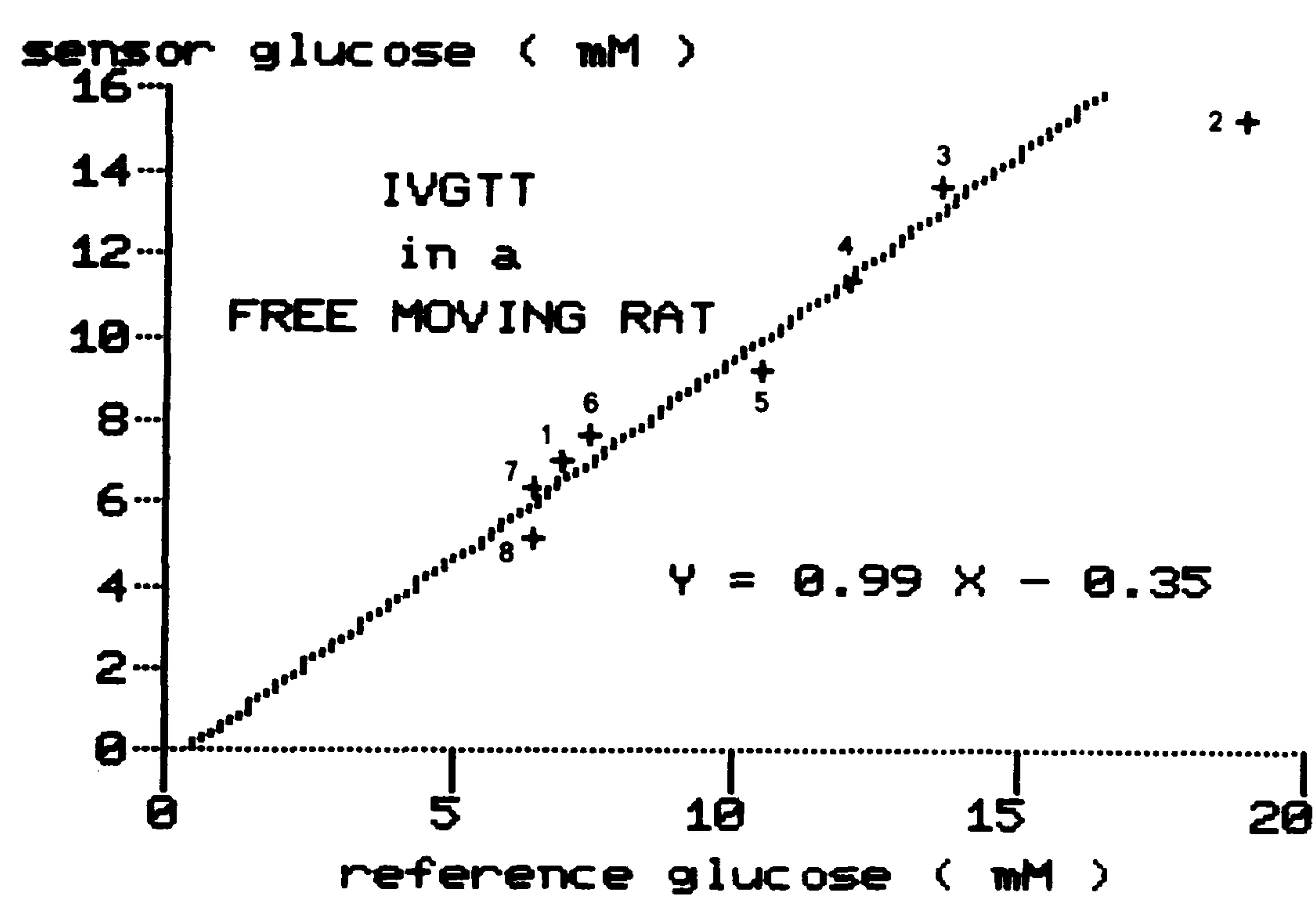

Fig. 3. Comparison of glucose values obtained with in vivo calibration before IVGTT and reference values using Beckman glucometer. A 4.5 min time-lag of the sensor, including 3.0 min response time and 1.5 min external circulation time has been taken into account for this comparison. Figures refer to blood samples identification numbers plotted on Figure 2 .

\section{Acknowledgements}

The work from my laboratory summarized in this review was supported by the Centre National de la Recherche Scientifique (Laboratoire associé LA 329). These results would not have been possible without the efforts of R. Sternberg, T. Tallagrand and G. Reach MD.

\section{REFERENCES}

1. H. W. Nürnberg, "Bioelectrochemistry I," G. Milazzo and M. Blank, eds., Plenum Press, London (1983).

2. C. Jacubowitz, L. T. Yu, and J. A. Reynaud, Electrochem.Acta, 28(1):57 (1983).

3. W. F. Smyth, "Polarography of Molecules of Biological Significance," p.326, Academic Press, London (1979).

4. W. F. Smyth, Electroanalysis in hygiene, environmental, clinical and pharmaceutical chemistry, Anal.Chem.Symp.Ser., 2:473 (1980).

5. W. J. Albery, M. Fillenz, N. J. Goddard, M. E. McIntyre, and R. D. O'Neil1, J.Physiol., 132:107 (1982).

6. R. N. Adams and C. A. Marsden, "Handbook of Psychopharmacology," Plenum Press, 15:1-74 (1982).

7. W. N. Brooks, C. E. W. Hahn, P. Foex, P. Maynard, and W. J. Albery, Br.J.Anaesth., 52:715-722 (1980).

8. R. M. Wightman, this volume p. (1985).

9. G. J. Patriarche and J. C. Vire, Anal.Chem. Symp.Ser., 2:209-225 (1980).

10. S. Bruckenstein and D. C. Johnson, Anal.Chem., 36:2186 (1964).

11. W. J. Albery, S. Bruckenstein, and D. C. Johson, Trans.Faraday Soc., 62:1938 (1966).

12. W. J. Albery and M. L. Hitchman, "Ring-disc Electrodes," Oxford Science Research Papers, Clarendon Press, Oxford (1971).

13. F. Rauwel and D. R. Thévenot, J.Applied Electrochem., 6:119-126 (1976).

14. F. Rauwel and D. R. Thévenot, Bioelectrochem.Bioenergetics, 3:284-301 (1976).

15. F. Rauwel and D. R. Thévenot, J.Electroanal.Chem., 75:579-593 (1977).

16. W. J. Albery, N. J. Godelard, T. W. Beck, M. Fillenz, and R. D. 
O'Nei11, J.Electroanal.Chem., 161:221-233 (1984).

17. N. Lakshiminarayanaiah, "Membrane Electrodes," p.368, Academic Press, New York (1976).

18. K. Camman, "Das Arbeiten mit Ionenselektiven Elektroden," p.227, Springer Verlag, Berlin (1977).

19. P. C. Meier, D. Ammann, H. F. Osswald, and W. Simon, Med.Prog.Technol., 5:1-12 (1977).

20. P. Bergveld and N. F. de Rooij, "Proc. Int. Conf. on Monitoring Vital Parameters," p.113, Nijmegen, Karger (1981).

21. J. D. Czaban, A. D. Comier, and K. D. Legg, Clin.Chem., 28:1936-45 (1982).

22. J. H. Ladenson, F. S. Apple, J. J. Aguanno, and D. D. Koch, C1in.Chem., 28:2383 (1983).

23. W. McD. Armstrong, W. McD. Wojtkowski, and W. R. Bixenman, Biochim. Biophys.Acta, 465:165-170 (1977).

24. R. A. Steiner, M. Ochme, D. Amman, and W. Simon, Anal.Chem., 51(3):351 (1979).

25. W. Crowe, A. Mayevsky, and L. Mela, Am.J.Physiol., 233(1):C56-C60 (1977).

26. K. Shimada, Y. Yano, K. Shibatani, Y. Komoto, M. Esashi, and T. Matsuo, Med.Biol.Eng.Comp., 18:741 (1981).

27. G. Koning and S. J. Schepel, in: "Proc. Int. Meeting on Chemical Sensors," T. Seiyama, K. Fueki, J. Shiokawa, and S. Suzuki, eds., p.597-602, Elsevier, Amsterdam (1983).

28. M. R. Neuman, "Theory Design and Biomedical Applications of Solidstate Chemical Sensors," C.R.C. Press, p.277-287.

29. M. A. Jensen and G. A. Rechnitz, Anal.Chem., 51(12):1972 (1979).

30. M. E. Lopez and G. A. Rechnitz, Anal.Chem., 54(12):2085 (1982).

31. C. E. W. Hahn, J.Phys.Sci.Instrum., 13:470 (1982).

32. H. P. Kimmich, F. Kreuzer, J. G. Spaan, K. Jank, de J. Hemptinne, and M. Demeester, Adv.Exp.Med.Biol., 75:33-40 (1976).

33. B. Hagihara, K. Kurosawa, S. Hashimoto, H. Sugimoto, and T. Sugimoto, in: "Proc. Int. Meeting on Chemical Sensors," T. Seiyama, K. Fueki, J. Shiokawa, and S. Suzuki, eds., p.591-596, Elsevier, Amsterdam (1983).

34. R. Huch, D. W. Lubbers, and A. Huch, Arch.Disease in Childhood, 49:213 (1974).

35. J. L. Peabody, G. A. Gregory, M. M. Willis, and W. H. Tooley, Am.Rev. Respir.Disease, 118:83-87 (1978).

36. 0. Löfgren and L. Jacobson, Acta.Paediatr.Scand., 68:789 (1979).

37. B. Hagihara, K. Kogo, K. Nakayama, S. Shiraishi, M. McCabe, and S. Ohkawa, Jap.J.Med.Electr.Biol.Eng., 18:262 (1980).

38. P. Eberhard and R. Schäffer, J.Clin.Eng., 6:36 (1981).

39. G. G. Guilbault, in: "Immobilized Enzymes, Antibodies and Peptides," H. H. Weetal1, ed., p.293-417, Dekker, New York (1975).

40. D. R. Thévenot, Diabetes Care, 5(30):184-189 (1982).

41. G. Rechnitz, Science, 214:287-291 (1981).

42. S. Suzuki and I. Karube, Applied Biochem.Bioeng., 3:145-174 (1981).

43. L. C. Clark and C. Lyons, Ann.NY.Acad.Sci., 102:29-45 (1962).

44. D. R. Thévenot, P. R. Coulet, R. Sternberg, and D. C. Gautheron, Bioelectrochem.Bioenerg., 5:548-553 (1978).

45. D. R. Thévenot, R. Sternberg, P. R. Coulet, J. Laurent, and D. C. Gautheron, Anal.Chem., 51:96-100 (1979).

46. J. L. Romette, B. Froment, and D. Thomas, C1in.Chim.Acta, 95: 249 (1979).

47. G, Durliat, M. Comtat, J. Mehenc, and A. Baudras, Anal.Chim.Acta, $85: 31-40$ (1976).

48. P. Abe1, U. Fischer, and E. J. Freyse, Life support systems, J.Europ.Soc.Artif.Organs, suppl.1, 94-97 (1982).

49. P. Abel, U. Fischer, A. Muller, and E. J. Freyse, Life support systems, J.Europ.Soc.Artif.Organs, supp1.1, 45-48 (1983). 
50. M. Shichiri, R. Kawamori, Y. Yamasaki, N. Hakui, and H. Abe, The Lancet,

pp.1129-1131 (1982).

51. M. Shichiri and R. Kawamori, Diabetologia, 24:179-184 (1983). 